\title{
Characterization of phosphate structures in biochar from swine bones
}

\author{
Etelvino Henrique Novotny(1), Ruben Auccaise(1), Marcia Helena Rodrigues Velloso(2), Juliano Corulli Corrêa( ${ }^{(3)}$, \\ Martha Mayumi Higarashi( ${ }^{(3)}$, Valéria Maria Nascimento Abreu ${ }^{(3)}$, José Dilcio Rocha ${ }^{(4)}$ and Witold Kwapinski ${ }^{(5)}$
}

\begin{abstract}
(1)Embrapa Solos, Rua Jardim Botânico, no 1.024, CEP 22460-000 Rio de Janeiro, RJ, Brazil. E-mail: etelvino@cnps.embrapa.br, rauccaise@ursa.ifsc.usp.br (2)Centro Universitário Norte do Espírito Santo, Departamento de Ciências Naturais, BR 101 Norte, Km 60, CEP 29932-540 São Mateus, ES, Brazil. E-mail: marcia.velloso@ufes.br ${ }^{(3)}$ Embrapa Suínos e Aves, BR 153, Km 110, Caixa Postal 21, CEP 89700-000 Concórdia, SC, Brazil. E-mail: juliano@cnpsa.embrapa.br, martha@cnpsa.embrapa.br, valeria@cnpsa.embrapa.br (3)Embrapa Agroenergia, Parque Estação Biológica, s/no, CEP 70770-901 Brasília, DF, Brazil. E-mail: jose.rocha@embrapa.br (4)University of Limerick, Department of Chemical and Environmental Sciences, Carbolea Group, Limerick, Ireland. E-mail: witold.kwapinski@ul.ie
\end{abstract}

\begin{abstract}
The objective of this work was to develop an alternative methodology to study and characterize the phosphate crystalline properties, directly associated with solubility and plant availability, in biochar from swine bones. Some phosphate symmetry properties of pyrolyzed swine bones were established, using solid state nuclear magnetic resonance spectroscopy, principal component analysis, and multivariate curve resolution analysis, on four pyrolyzed samples at different carbonization intensities. Increasing carbonization parameters (temperature or residence time) generates diverse phosphate structures, increasing their symmetry and decreasing the crossed polarizability of the pair ${ }^{1} \mathrm{H}^{-31} \mathrm{P}$, producing phosphates with, probably, lower solubility than the ones produced at lower carbonization intensity. Additionally, a new methodology is being developed to study and characterize phosphate crystalline properties directly associated with phosphate solubility and availability to plants.
\end{abstract}

Index terms: bone phosphate, phosphate availability, principal component analysis, pyrolysis, multivariedade curve resolution analysis, soil fertility.

\section{Caracterização da estrutura de fosfatos em "biochar" de ossos suínos}

Resumo - O objetivo deste trabalho foi desenvolver uma metodologia alternativa para o estudo e a caracterização de propriedades cristalinas de fosfatos, diretamente associadas à sua solubilidade e disponibilidade para as plantas, em "biochar" de ossos de suínos. Foram estabelecidas algumas propriedades de simetria dos fosfatos de ossos pirolisados de suínos, por meio de espectroscopia de ressonância magnética nuclear no estado sólido, análise de componentes principais e análise multivariada de resolução de curvas, em quatro amostras pirolisadas em diferentes intensidades de carbonização. $\mathrm{O}$ aumento nos parâmetros de carbonização (temperatura ou tempo de residência) geram diferentes estruturas de fosfatos, com aumento de sua simetria e diminuição da polarizabilidade cruzada do $\operatorname{par}^{1} \mathrm{H}^{-31} \mathrm{P}$, o que resultou na síntese de fosfatos, provavelmente com menor solubilidade do que os produzidos com menor intensidade de carbonização. Além disso, uma nova metodologia está sendo desenvolvida para estudar e caracterizar as propriedades cristalinas de fosfatos diretamente relacionadas à sua solubilidade e disponibilidade para as plantas.

Termos para indexação: fosfato de ossos, disponibilidade de fósforo, análise de componentes principais, pirólise, análise de resolução de curvas multivariadas, fertilidade do solo.

\section{Introduction}

The intensive livestock production results in massive amounts of animal residues, such as chicken litter, dairy manure, and bones. Due to sanitary questions - as bovine spongiform encephalopathy (Moynagh \& Schimmel, 1999) - the use of bone as feed for animals was banned, and a potential destination for this material is pyrolysis, seeking the production of biofuels and biochar, i.e. pyrolyzed biomass to be used as soil amendment (Cheung et al., 2001; Walker \& Weatherley, 2001; Purevsuren et al., 2004).

Due to chemical composition of bones, biochar originating from them should be rich in phosphorus and calcium, important nutrients for plants. In many cases, the percentage of each mineral defines the crystal structure of phosphates (Rothwell et al., 1980), and can be modified by thermal procedures. Therefore, those residues can be transformed in a sterile agricultural

Pesq. agropec. bras., Brasília, v.47, n.5, p.672-676, maio 2012 
input, with a great variety of nutrient solubility, according to the thermal treatment used.

In general, apatites $\left[\mathrm{Ca}_{10}\left(\mathrm{PO}_{4}\right)_{6} \mathrm{X}\right]$ are compounds which have an analogous crystallographic structure to hydroxyapatite $\left[\mathrm{X}=(\mathrm{OH})_{2}\right]$, such as: carbonatoapatites $\left[\mathrm{X}=\mathrm{CO}_{3}\right]$ (Kaflak-Hachulska et al., 2003, 2006); carbonatohydroxyapatites (Aue et al., 1984; Roufosse et al., 1984); fluorapatites $\left[\mathrm{X}=(\mathrm{F})_{2}\right]$; and many others (Rothwell et al., 1980).

The major mineral phase of bone was found to be similar to hydroxyapatite, by an X-ray diffraction. Nevertheless, the exact chemical and structural nature of the solid phase of calcium phosphate in bones is still unclear, and the presence of brushite-like structures $\left(\mathrm{CaHPO}_{4} \cdot 2 \mathrm{H}_{2} \mathrm{O}\right)$ is controversial.

The contribution of apatite structures to bone composition is important and depends on the animal species and age (Wu et al., 2003). One of the main parameters of phosphates is solubility (Wu et al., 1994), which differs by 1 to 4 orders of magnitude in the $\mathrm{pH}$ range of $5-6.5$, depending on the phosphate chemical and crystallographic structure. Due to the fact that the X-ray diffraction technique generally fails to identify bone mineral phases, it will probably fail to characterize bone biochars as well. This happens because bone mineral crystallites are very small (Aue et al., 1984), and the resulting X-ray diffraction patterns are too poorly defined to permit a unique solution of its structural analysis (Herzfeld et al., 1980).

${ }^{31} \mathrm{P}$ solid state nuclear magnetic resonance (NMR) is an important technique to study brushite, hydroxyapatite $\left[\mathrm{Ca}_{10}(\mathrm{OH})_{2}\left(\mathrm{PO}_{4}\right)_{6}\right]$, and mixture samples of them (Kaflak-Hachulska et al., 2000, 2003, 2006), as well as to study and to characterize phosphorous vicinity (Aue et al., 1984; Wu et al., 2003). Nonetheless, strong signal overlapping and subtle differences appear on NMR spectra due to sample complexity. Therefore, multivariate methods, such as principal component analysis (PCA) and multivariate curve resolution (MCR), are used to improve the interpretability of the results.

The objective of this work was to develop an alternative procedure to obtain information about crystal structures of pyrolized swine bones using ${ }^{13} \mathrm{C}$ and ${ }^{31} \mathrm{P}-\mathrm{NMR}$ spectra and multivariate tools.

\section{Materials and Methods}

Samples of biochar from swine bones, obtained under four different pyrolysis parameters, were submitted to
NMR characterization. The evaluated temperatures and residence times were: sample $1,930^{\circ} \mathrm{C}$ for $10 \mathrm{~min}$; sample $2,300^{\circ} \mathrm{C}$ for $45 \mathrm{~min}$ followed by $500^{\circ} \mathrm{C}$ for $7 \mathrm{~min}$; sample $3,300^{\circ} \mathrm{C}$ for $25 \mathrm{~min}$ followed by $500^{\circ} \mathrm{C}$ for $10 \mathrm{~min}$; and sample $4,500^{\circ} \mathrm{C}$ for $60 \mathrm{~min}$. The samples 1 to 3 were produced in a modified incinerator with limited air input, while the sample 4 was produced in a fluidized pyrolysis plan-temperature of inert silica bed of $500^{\circ} \mathrm{C}$; vapor-residence time of $2 \mathrm{~s}$; and solid-residence time of 1 hour.

The characterization of the biochar samples was performed using the NMR at $500 \mathrm{MHz}$ Varian spectrometer (Varian, Inc., Palo Alto, CA, USA). For this, a T3NB HXY of $4 \mathrm{~mm}$ probe (Varian, Inc., Palo Alto, CA, USA) was utilized to detect ${ }^{13} \mathrm{C}$ and ${ }^{31} \mathrm{P}$ nuclei, and the rotors were spun using dry air at $15 \mathrm{kHz}$ for ${ }^{13} \mathrm{C}$, and $2 \mathrm{kHz}$ and $10 \mathrm{kHz}$ for ${ }^{31} \mathrm{P}$ experiments. All experiments were carried out at room temperature.

Two NMR-pulse procedures were applied: cross-polarization (CP) and direct polarization (DP) at magic-angle spinning (MAS). In the CP-MAS experiment with ${ }^{13} \mathrm{C}\left({ }^{31} \mathrm{P}\right)$ nuclei, an optimized recycle delay $\left(\mathrm{d}_{1}\right)$ of $500 \mathrm{~ms}(10 \mathrm{~s})$ was used, the proton 90-pulse was set to $3 \mu \mathrm{s}$; the contact time value to $1 \mathrm{~ms}(0.5 \mathrm{~ms})$; the acquisition time to $15 \mathrm{~ms}(15 \mathrm{~ms})$; and the number of scans to 4,096 (1). In the DP-MAS experiment, the recycle delay was of $10 \mathrm{~min}$, and ${ }^{31} \mathrm{P}$ 90 -pulse was set to $3 \mu \mathrm{s}$, acquisition time to $15 \mathrm{~ms}$ and the number of scans to 1 .

Principal component analysis (PCA) was used to seek for data reduction and sample classification. It is a powerful tool to show data structure, i.e. the interrelationship among the variables (in the present case, the spectra signal intensities). PCA procedure is mainly dependent on the covariance matrix $\mathrm{C}=\mathrm{E}\left[(\mathrm{x}-\mu)(\mathrm{x}-\mu)^{\mathrm{T}}\right], \mu=\mathrm{E}[\mathrm{x}]$, of the original data, in which $\mathrm{x}$ is a sample set vector, and $\mu$ is the estimated mean vector of the sample set. The eigenvalues $\lambda_{1}, \lambda_{2}, \ldots, \lambda_{\mathrm{n}}$ were estimated and the respective eigenvectors $\mathrm{u}_{1}, \mathrm{u}_{2}, \ldots, \mathrm{u}_{\mathrm{n}}$ from the covariance matrix $\mathrm{C}$, such that the eigenvalues $\lambda$ were real and nonnegative. Next, it was necessary to index the decrease of the $\lambda$ values $\lambda_{1}>\lambda_{2}>\ldots>\lambda_{n}$. The reconstruction of $x^{*}$ was obtained as:

$\mathrm{x}^{*}=\sum_{\mathrm{i}=1}^{\mathrm{p}}\left(\mathrm{x}^{\mathrm{T}} \mathrm{u}_{\mathrm{i}}\right) \mathrm{u}_{\mathrm{i}}$ with $\mathrm{p}, \mathrm{p}<\mathrm{n}$, representing the desired quality reconstruction.

In the MCR procedure, the initial step is to perform a PCA, to estimate the number of components in the 
mixture. Then, the PC rotation could be calculated; but, since the orthonormality constrains are relaxed, it would present infinite solutions. To solve this, new constrains must be imposed, such as nonnegative concentrations and nonnegative spectra (Novotny et al., 2009).

For the multivariate data analysis, the full NMR spectra were renormalized before the PCA and the MCR analysis.

\section{Results and Discussion}

Biochar from swine bones, produced at high temperature or residence times, resulted in a decreased carboxyl and amide functionalities, and in an increased and broad aromatic signal in the ${ }^{13} \mathrm{C}-\mathrm{NMR}$ spectra, indicating great carbonization (Figure 1). Based on that, the carbonization intensity would be: sample $1<$ sample $3<$ sample $2=$ sample 4. Additionally, all the biochars showed significant amorphous polymethylene signals (30 ppm), which is an important feature for the adsorption of nonpolar compounds (Mao et al., 2002), such as pesticides, and for carbon sequestration purposes (Simpson et al., 2007).

The MAS spectrum consisted of a centerband at the isotropic chemical shift of $2.7 \mathrm{ppm}$, typical of phosphate, flanked by a series of sidebands spaced at the spinning frequency (Figure 2). Looking at the spinning sideband intensity, it is possible to verify that the sample 1, submitted to shorter carbonization

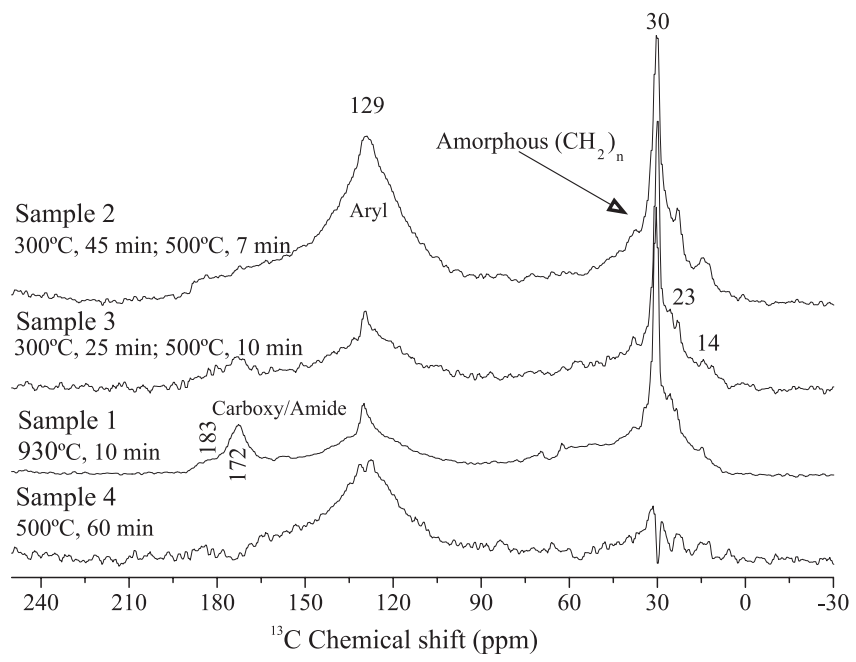

Figure 1. ${ }^{13} \mathrm{C}-\mathrm{NMR}$ spectra of swine bone biochars, using the CP-MAS NMR, with $18 \mathrm{kHz}$ of MAS. time, showed a higher intensity for the bands, which indicates that low-carbonization intensity results in a high amount of ${ }^{31} \mathrm{P}$ compounds with lower symmetry than the ones of other samples, which were subjected to a more intensive carbonization. Wu et al. (2003) concluded that the chemical shift anisotropy - which originates the spinning sidebands - decreases with increasing bone mineralization and mineral maturity, and with decreasing protein-phosphoryl content.

The present data confirms these observations, since the carbonization cause a mineralization of the bones

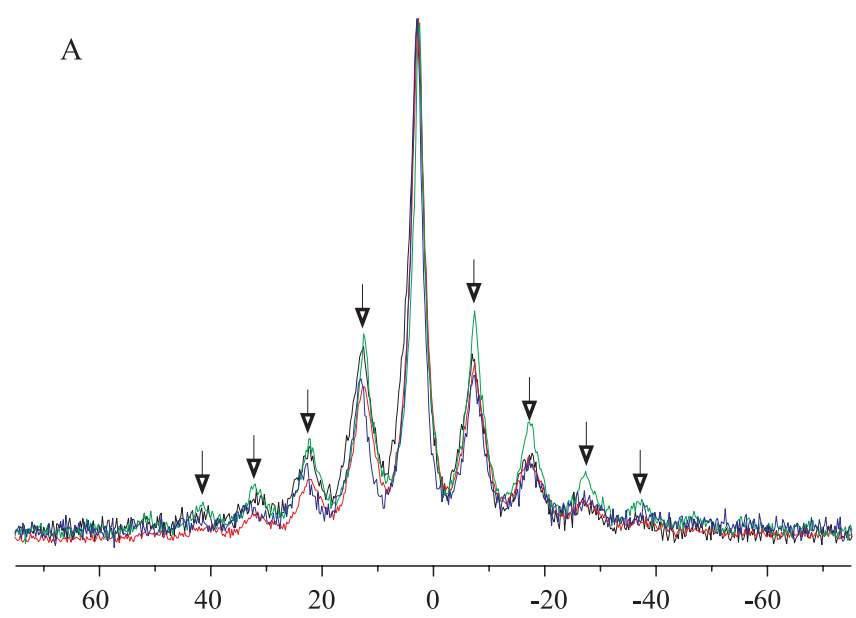

B

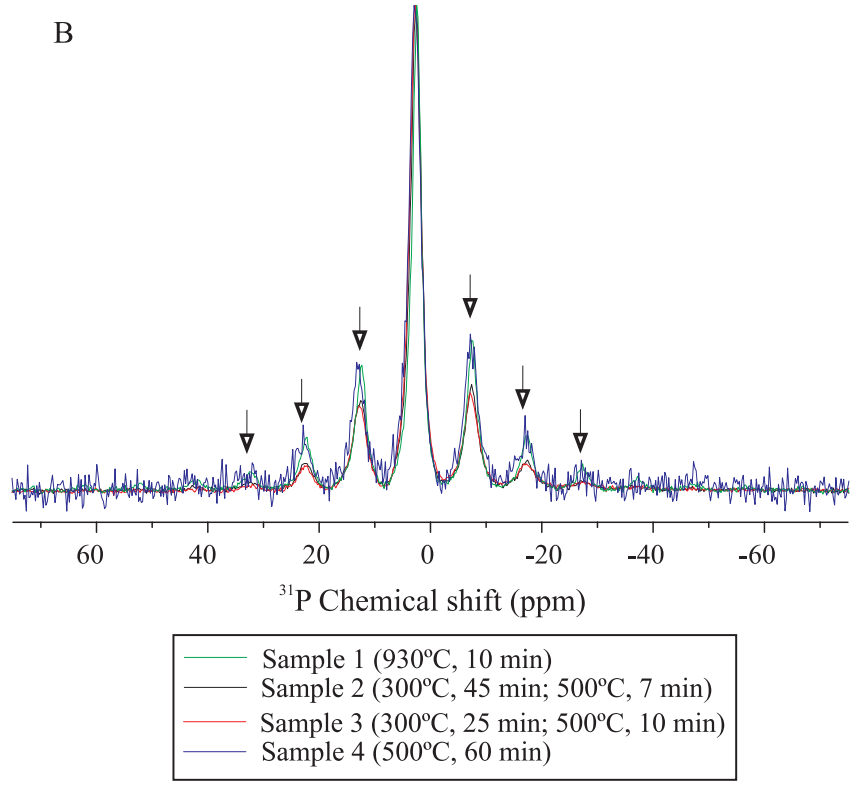

Figure 2. ${ }^{31} \mathrm{P}-\mathrm{NMR}$ spectra of swine bone biochars using: A, CP-MAS NMR; and B, DP-MAS NMR with $2 \mathrm{kHz}$ of MAS. Arrows indicate spinning sidebands. 
and also a probably destruction of protein phosphoryl compounds, as it was verified by the ${ }^{13} \mathrm{C}-\mathrm{NMR}$ results. This has an agronomical importance, since the increase of the mineral maturity towards hydroxyapatite decreases the phosphate solubility.

Interesting is the comparison between $\mathrm{CP}$ and DP results: the contribution of spinning sideband signal intensity for the whole spectra is greater for the $\mathrm{CP}$ than for the DP experiment, indicating that the lower-symmetry phosphate shows an easier ${ }^{1} \mathrm{H}-{ }^{31} \mathrm{P}$ cross-polarization, since its spinning sideband is maximized under $\mathrm{CP}$. The ${ }^{1} \mathrm{H}-{ }^{31} \mathrm{P}$ cross-polarization efficiency decreases with the calcination at $800^{\circ} \mathrm{C}$ of synthetic hydroxyapatite, due to dehydration and that consequently decreases the number of ${ }^{1} \mathrm{H}$ per ${ }^{31} \mathrm{P}$ involved in CP within spin clusters (Kaflak-Hachulska et al., 2003).

Hydroxyapatite spectra are known to show a sharp centerband and weak sidebands, while brushite spectra show intense sidebands. This is due to the effects of chemical shift anisotropy (Rothwell et al., 1980; Aue et al., 1984) and the very easy polarization under CP-MAS (Kaflak-Hachulska et al., 2006).

The main information of the ${ }^{31} \mathrm{P}$ DP-MAS NMR spectra at $10 \mathrm{kHz}$ are shown by the sidebands (Figure 3), whose numbers were reduced by the effect of spinning rate, but its characteristic of anisotropy was maintained, i.e. sample 1 with lower symmetry than the other samples; this made the information provided by the sidebands still able to be used.

Considering those qualitative evidences, MCR was then employed in order to extract more information from the data. Therefore, ${ }^{31} \mathrm{P}$ NMR spectroscopy, principal component and multivariate curve resolution analyses were put together, and a binary mixture was set to fit the samples, by estimating the percentage of the two different phosphate groups in each sample, as well as of their respective spectra (Figure 4).

The studied biochar were considered a binary mixture with one component that cross-polarizes easily and shows a lower symmetry, probably due to its association with hydrated phosphate, than other biochars which cross-polarizes hardly and shows higher symmetry. The content of hydrated phosphate decreased with the increase of carbonization degree, and the estimated percentage varied from 100 to $20 \%$. Therefore, it is possible to conclude that different degrees of pyrolysis produce different proportions of phosphate species, indicating that swine bones, pyrolyzed under different conditions, can show a great diversity on solubility properties, which is an important characteristic for phosphate fertilizers.

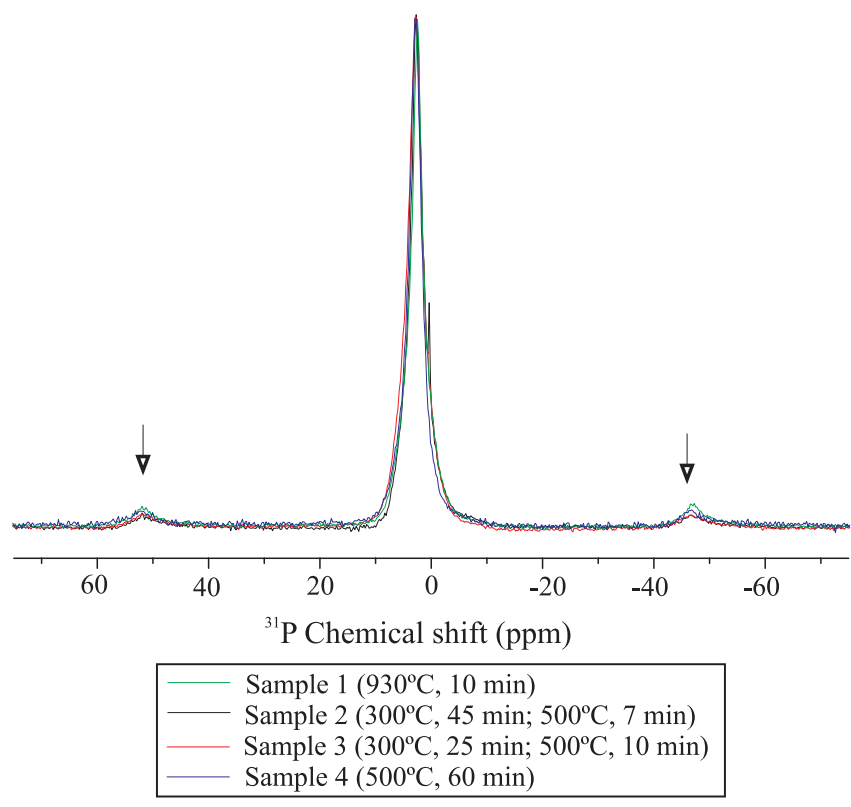

Figure 3. ${ }^{31} \mathrm{P}-\mathrm{NMR}$ spectra of swine bone biochars, using the DP-MAS NMR with $10 \mathrm{kHz}$ of MAS. Arrows indicate spinning sidebands.

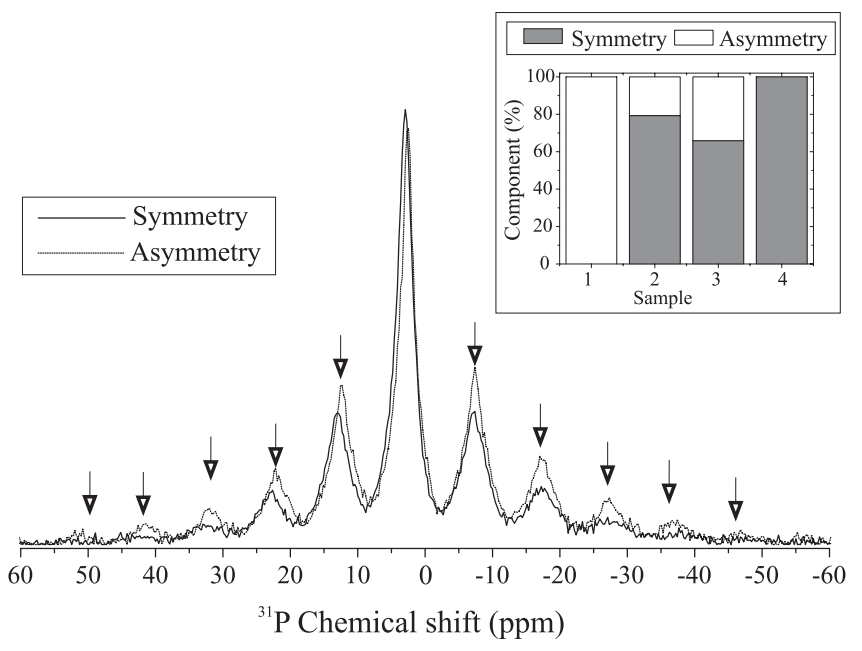

Figure 4. Multivariate curve resolution analysis about ${ }^{31} \mathrm{P}$ nuclei from the CP-MAS $(2 \mathrm{kHz})$ experimental data. Symmetry and asymmetry refer to the higher or lower-symmetry species, respectively. Arrows indicate spinning sidebands. 


\section{Conclusions}

1. Pyrolyzed swine bones have a potential to perform as a phosphorus fertilizer source, by using different temperature and residence time during their carbonization production.

2. Swine bones, pyrolyzed under different conditions, have different phosphate species, with different solubility and P-release rates.

3. The joint performance of NMR spectroscopy and chemiometric tools can extract information of apparently hidden physical properties, as the case of chemical-shift anisotropy.

\section{Acknowledgements}

To Fundação de Amparo à Pesquisa do Estado do Rio de Janeiro, for financial support; to Conselho Nacional de Desenvolvimento Científico e Tecnológico, and to Coordenação de Aperfeiçoamento de Pessoal de Nível Superior, for fellowships; to Jasmin Lemke, for assistance with text proof reading.

\section{References}

AUE, W.P.; ROUFOSSE, A.H.; GLIMCHER, M.J.; GRIFFIN, R.G. Solid-state phosphorus-31 nuclear magnetic resonance studies of synthetic solid phases of calcium phosphate: potential models of bone mineral. Biochemistry, v.23, p.6110-6114, 1984.

CHEUNG, C.W.; CHAN, C.K.; PORTER, J.F.; MCKAY, G. Combined diffusion model for the sorption of cadmium, copper, and zinc ions onto bone char. Environmental Science and Technology, v.35, p.1511-1522, 2001.

HERZFELD, J.; ROUFOSSE, A.; HABERKORN, R.A.; GRIFFIN, R.G.; GLIMCHER, M.J. Magic angle sample spinning in inhomogeneously broadened biological systems. Philosophical Transactions of the Royal Society of London Series B: Biological Sciences, v.289, p.459-469, 1980.

KAFLAK-HACHULSKA, A.; CHMIELEWSKI, D.; GORECKI, A.; SLOSARCZYK, A.; KOLODZIEJSKI, W. Efficiency of ${ }^{1} \mathrm{H}_{-}{ }^{31} \mathrm{P}$ NMR cross polarization in bone apatite and its mineral standards. Solid State Nuclear Magnetic Resonance, v.29, p.345-348, 2006

KAFLAK-HACHULSKA, A.; SAMOSON, A.; KOLODZIEJSKI, W. ${ }^{1} \mathrm{H}$ MAS and ${ }^{1} \mathrm{H}^{31} \mathrm{P} \mathrm{CP} / \mathrm{MAAS}$ NMR study of human bone mineral. Calcified Tissue International, v.73, p.476-486, 2003.
KAFLAK-HACHULSKA, A.; SLOSARCZYK, A.; KOLODZIEJSKI, W. Kinetics of NMR cross-polarization from protons to phosphorous-31 in natural brushite. Solid State Nuclear Magnetic Resonance, v.15, p.237-238, 2000.

MAO, J.D.; HUNDAL, L.S.; THOMPSON, M.L.; SCHMIDT-ROHR, S. Correlation of poly(methylene)-rich amorphous aliphatic domains in humic substances with sorption of a nonpolar organic contaminant, phenanthrene. Environmental Science and Technology, v.36, p.929-936, 2002.

MOYNAGH, J.; SCHIMMEL, H. Test for BSE evaluated. Nature, v.400, p.105, 1999.

NOVOTNY, E.H.; HAYES, M.H.B.; MADARI, B.E.; BONAGAMBA, T.J.; AZEVEDO, E.R. de; SOUZA, A.A. de; SONG, G.; NOGUEIRA, C.M.; MANGRICH, A.S. Lessons from the Terra Preta de Indios of the Amazon region for the utilisation of charcoal for soil amendment. Journal of the Brazilian Chemical Society, v.20, p.1003-1010, 2009.

PUREVSUREN, B.; AVID, B.; GERELMAA, T.; DAVAAJAV, Y.; MORGAN, T.J.; HEROD, A.A.; KANDIYOTI, R. The characterisation of tar from the pyrolysis of animal bones. Fuel, v.83, p.799-805, 2004

ROTHWELL, W.P.; WAUGH, J.S.; YESINOWSKI, J.P. High-resolution variable-temperature ${ }^{31} \mathrm{P}$ NMR of solid calcium phosphates. Journal of the American Chemical Society, v.102, p.2637-2643, 1980.

ROUFOSSE, A.H.; AUE, W.P.; ROBERTS, J.E.; GLIMCHER, M.J.; GRIFFIN, R.G. Investigation of the mineral phases of bone by solid-state phosphorous-31 magic angle sample spinning nuclear magnetic resonance. Biochemistry, v.23, p.6115-6120, 1984.

SIMPSON, A.J.; SONG, G.; SMITH, E.; LAM, B.; NOVOTNY, E.H.; HAYES, M.H.B. Unraveling the structural components of soil humin by use of solution-state nuclear magnetic resonance spectroscopy. Environmental Science and Technology, v.41, p.876-883, 2007.

WALKER, G.M.; WEATHERLEY, L.R. Absortion of dyes from aqueous solution - the effect of adsorbent pore size distribution and dye aggregation. Chemical Engineering Journal, v.83, p.201-206, 2001.

WU, Y.; ACKERMAN, J.L.; STRAWICH, E.S.; REY, C.; KIM, H.-M.; GLIMCHER, M.J. Phosphate ions in bone: identification of a calcium-organic phosphate complex by ${ }^{31} \mathrm{P}$ solid state NMR spectroscopy at early stages of mineralization. Calcified Tissue International, v.72, p.610-626, 2003.

WU, Y.; GLIMCHER, M.J.; REY, C.; ACKERMAN, J.L. A unique protonated phosphate group in bone mineral not present in synthetic calcium phosphates. Journal of Molecular Biology, v.244, p.423-435, 1994.

Received on January 31, 2011 and accepted on April 23, 2012 